\title{
An Experimental Study of Flipped Classroom English Teaching Based on Autonomous Learning Theory
}

\author{
Min Yao \\ College of Foreign Languages, Hunan Agricultural University, Changsha City, Hunan, 410000, China
}

\begin{abstract}
In order to improve students' English autonomous learning abilities, the study applied the flipped classroom teaching model based on autonomous learning theory. According to the experimental data analysis and the survey, it is found that flipped classroom teaching plays a more positive role in cultivating students' autonomous learning ability, improving their comprehensive English proficiency, and building their confidence and interest in college English learning.
\end{abstract}

Keywords: Flipped classroom; College English teaching; Autonomous learning theory

DOI: http : //dx.doi.org/10.26549/jetm.v2i1.685

\section{Introduction}

$\mathrm{I}$ n 2007, the College English Curriculum Requirements by Department of Higher Education of Education Ministry called for enhancing students' ability to study independently ${ }^{[1]}$ No more than ten years later, the Guidance for College English Teaching(2016), when talking about the curriculum provision, demanded that colleges and universities should balance classroom teaching and learners' autonomous learning, establish teaching models suited to different types of courses and different levels of requirements, and promote the forming of learners' individualized learning strategies and development of learners' autonomous learning skills. What's more, colleges and universities should take network courses into consideration of curriculum provision, and pay much attention to the construction of online courses, putting related courses on the network teaching platform, seamlessly integrating classroom teaching and net-based learning. ${ }^{[2]}$

Under the curriculum requirements and teaching models, it is the primary task for college English teachers to cultivate learners' autonomous learning abilities, making full use of the network teaching platform. Teachers help to develop learners' autonomous learning and improve their comprehensive language abilities. Also, learners develop the abilities of self-management and self-learning, and the cognitive competence of observation, memory, imagination and thinking.

In recent years, the emergence of flipped classroom teaching has expanded the range of English teaching. This study stemmed from a concern in 2016 that my non-English major students' performances were reflecting lower autonomous learning. For example, students 'seemed' to be doing what I assigned to them at the last minute, copying and pasting the answers from online sources. When I asked them to raise their questions, most of them could say nothing, which indicated that they hadn't previewed or reviewed. To satisfy the curriculum requirements and help students to improve their autonomous learning abilities, in 2016, my colleagues and I introduced the teaching model of "flipped classroom", attempting to develop the college English teaching towards "learner-centered" teaching, providing learners with more time and space for autonomous learning.

Subject: This article is the initial achievement of the teaching reform program "Study of College English Teaching Based on the Idea of Flipped Classroom" in Hunan Agricultural University.

Author's Information: Min Yao is a Chinese English teacher, whose research focuses on college English teaching and higher education theory. She works as a English teacher in College of Foreign Languages, Hunan Agricultural University.

Corresponding Author: Min Yao, tabitha1998@163.com 


\section{The Theory of Autonomous Learning and the "Flipped Classroom" Teaching}

Background of autonomous learning theory: With the development of cognitive psychology, humanistic psychology and constructivism learning theory, the research focused on learners, especially adult learners, and their abilities of autonomous learning strategies. First, in the early 1960s, western educationists advocated that cultivating learners' responsibilities was the ultimate goal of education. The issues such as "learner training", i.e. "learn to learn" or "intelligence development", "learner-skill training" and "key-skill training" attracted educationists, who transferred their research from learners' external environment to the development of learners' subjective initiative. What's more, the theory of humanistic learning put forward by Carl Rogers, an American humanistic psychologist, which put emphasis on the learning process, learners' dominant role and their potential, and emphasized the importance of self-assessment, provided theoretic bases for viewpoint of foreign language learners' autonomy. Therefore, the teaching should focus on promoting learners' learning process, meaningful learning and learners' all-round development of personality. ${ }^{[3]}$

Furthermore, Jean Piaget, a Swiss psychologist and outstanding representative of constructivism, stated that learning was under a certain cultural interest, with others' help, making use of necessary resources, through the way of meaningful access to knowledge construction process. Constructivism also stressed that learner-centered create a free and relaxing learning environment, practice cooperative learning, checking and revising one's recognition by communicating with others, and make it in accordance with the learning law.

The constructivism of autonomous learning has often been misunderstood. Some wrongly think it is learners' self-study, without teachers' instructions, and even teachers' role is unnecessary. In fact, we can interpret autonomous learning from different aspects. Holec (1981) defined learners' abilities from learning objects, contents and course, learning methods and strategies, learning process as well as learning effects/outcomes. ${ }^{[4]}$ Dickinson(1987) stated that autonomous learning was both a kind of attitude and an independent learning ability. ${ }^{[5]}$ Zimmer$\operatorname{man}(1989)$ thought autonomous learning was related to learners' environment, both physical and social conditions. ${ }^{[6]}$ Little(1991) from cognitive psychological aspect summarized that learning was the ability of critical thinking, making decisions on their own, emphasizing teachers' role in autonomous learning. ${ }^{[7]}$ Weiguo Pang(2007) revealed the collocation of autonomous learning from the horizontal and vertical dimensions. From the horizontal dimen- sion, he defined autonomous learning from many aspects, such as the driving motivation, the choosing of learning contents, the adjustment of learning strategies, and time allotment, etc. From vertical dimension, he explained the essence of autonomous learning through the whole learning process. ${ }^{[8]}$

\section{Flipped Classroom}

"Flipped classroom" teaching is an instructional strategy and a type of blended learning that reverses the traditional learning environment by delivering instructional content, which is often conducted online, outside of the classroom. It moves activities, including those that may have traditionally been considered homework, into the classroom. In a flipped classroom, students watch online lectures, collaborate in online discussions, or carry out research at home and engage in concepts in the classroom with the guidance of a mentor.

According to "Flipped classroom" teaching models, learners choose the best way for them to learn. Although teachers' authority is challenged, learners' knowledge internalization is strengthened (reinforced). It is more convenient to have communication between learners and between teachers and learners.

In the field of flipped classroom teaching, there is a substantial body of research relating to the importance of flipped classroom teaching and students' English competence improvement, the design and construction of flipped classroom teaching(SHAO Hua \& YU Hui-qun 2015; LONG Han 2015; CUI Yanhui \& WANG Yi 2014; DENG Di 2016; BU Caili \&ZHANG Baohui2016), ${ }^{[9-13]}$ or the prospect of flipped classroom teaching in the future (HE Kekang2014). ${ }^{[14]}$ However, the autonomous learning ability of students has not been carefully explored. It should be noted that without careful investigation of flipped classroom teaching, it is impossible to know how it affects students' autonomous learning ability. Further study of flipped classroom teaching based on autonomous learning theory is needed. For that reason, this research aims at applying flipped classroom teaching model in English teaching for non-English majors and promoting learners' autonomous learning abilities.

\section{Experimental Research of Flipped Classroom Teaching}

\subsection{Research Plan}

\subsubsection{The Object of Experiment}

Under the instructions of autonomous learning theory, we applied the flipped classroom teaching model in the English teaching for non-English majors, which lasted for a semester, to find a better teaching model more suitable to 
learners, and to promote learners' comprehensive ability.

\subsubsection{Hypothesis}

Hypothesis 1: The experimental group and control group are of the same level in English.

Hypothesis 2: Besides that the language comprehensive abilities, the experimental group are better than the control group in autonomous learning.

\subsection{Experimental Subjects}

The study chose two undergraduate classes of non-English majors of Grade 2016, of which the population was the same, both 27 , and the percentage of male and female was nearly the same. To guarantee the accuracy of the experiment, we complied a set of teat paper which was as difficult as the National College Entrance Examination English paper in 2016, and whose question patterns were the same as those of CET4, to test the two groups, which was the pretest. The time was 130 mintes. And the total score was 100 . According to the test results, the experimental group and control group were confirmed.

\subsection{Research Methods}

The study adopted qualitative and quantitative methods. Qualitative research mainly made questionnaires, interviews, homework-check, etc., while quantitative methods included the pre-test and post-test, which indicated the difference between pre-experiment and post-experiment.

\subsection{Implementation of the Experiment}

(1) The two groups were taught by the same teacher, one adopted the flipped classroom teaching model while the other in the traditional way, although the other conditions were the same. Action research method required that the experimental group know what they were doing, while control group did not.

(2) Both groups used the same teaching materials. Intensive reading materials and listening materials were New College English Integrated Course and New College English Course Listening and Speaking published by Shanghai Foreign Language Education Press, Besides, students had a two-period autonomous learning course, during which time students must finish the book of New Horizon College English Viewing, listening \& speaking, edited by Shutang Zheng and published by Foreign Language Teaching and Research Press. The two groups had the same teaching hours, that is, six periods a week, including intensive reading, listening and autonomous learning, with the same teaching progress and took part in the final ex- amination held by the university, which was also the posttest.

(3) The teachers have their own website. Before every class, teachers either uploaded the video or micro-course or PPT related to the teaching to the website or send the files to the students through QQ or WeChat. Students watched or read these materials in their free time, most of which were detailed explanation or analysis of vocabulary and grammar as well as background information of each topic. Students were asked to try to figure out the questions by themselves, otherwise they wrote down their questions and brought to the classroom to discuss with teachers or classmates. For those typical ones, teachers explained to the whole class. While with regards to the control group, the teacher adopted the traditional teaching, mainly lecturing and asking students questions. Students answered teachers' questions passively. At the same time, both the experimental group and the control group also had autonomous learning lesson, during which time they finished the book of viewing, listening and speaking.

\subsection{Analysis of the Experiment Result}

During the one-term experiment, the students had two tests, one pretest and the other final examination, i.e. posttest. Both the tests were of the same pattern, with the total score 100 , of which writing takes up $15 \%$, listening $30 \%$, reading $30 \%$, translation $15 \%$, cloze $10 \%$. The scores of both the groups are as the follows.

From Table 1, we can see that the two groups were of the same level. The control group was a little better than the experimental group except for the listening and cloze. And from the general scores, there were little disparity between the two groups. And as the following table shows, $p>0.05$, the difference is not significant.

\begin{tabular}{ccc}
\hline $\mathrm{t}$ & Degree of Freedom & Significance Level \\
\hline-.499 & 52 & .620 \\
\hline
\end{tabular}

Therefore, we concluded that the two groups' English disparity would not affect the study.

At the end of the study, we had a comprehensive assessment of the two groups, including formative assessment and summative assessment. Formative assessment consisted of attendance (10\%), autonomous learning $(10 \%)$, classroom participating (10\%) and group cooperation $(10 \%)$. According to the records, generally, the experimental group did a better job than the control group.

The post-test was more difficult than the pre-test. From

Table 1. Mean and standard deviation of pre-test

\begin{tabular}{|c|c|c|c|c|c|c|c|c|}
\hline Class & Population & General Mean & $\begin{array}{c}\text { Standard Deviation of the } \\
\text { General Score }\end{array}$ & Writing & Listening & Reading & Translation & Cloze \\
\hline The Experimental Group & 27 & 60.54 & 5.7 & 11.82 & 16.79 & 16.44 & 11.54 & 4.52 \\
\hline The Control Group & 27 & 61.35 & 5.4 & 11.93 & 16.64 & 16.85 & 11.83 & 4.48 \\
\hline
\end{tabular}


Table 2. Mean and standard deviation of post-test

\begin{tabular}{|c|c|c|c|c|c|c|c|c|}
\hline Class & Population & General Mean & $\begin{array}{c}\text { Standard Deviation of the } \\
\text { General Score }\end{array}$ & Writing & Listening & Reading & Translation & Cloze \\
\hline The Experimental Group & 27 & 67.55 & 5.6 & 11.22 & 16.70 & 20.89 & 13.24 & 4.61 \\
\hline The Control Group & 27 & 65.37 & 7.9 & 11.00 & 16.54 & 20.89 & 12.42 & 4.59 \\
\hline
\end{tabular}

Table 3. Comparison of general mean scores between pre-test and post-test

\begin{tabular}{|c|c|c|c|c|c|c|}
\multirow{2}{*}{ Tyse } & \multicolumn{5}{c|}{ Total Marks } \\
\cline { 2 - 8 } & \multicolumn{3}{|c|}{ MD } & \multicolumn{4}{c|}{ SD } \\
\cline { 2 - 8 } & Pre-test & Post-test & Deviation & Pre-test & Post-test & Deviation \\
\hline The Experimental Group & 60.54 & 67.55 & 7.01 & 5.7 & 5.6 & -0.1 \\
\hline The Control Group & 61.35 & 65.37 & 4.02 & 5.4 & 7.9 & 2.5 \\
\hline
\end{tabular}

Table 2, we can see that there was an obvious disparity between the two groups, that is, the experimental group did a better job than the control group in writing, listening and translation by $0.22,0.16$ and 0.17 more than those of the control group respectively. And the total score was 1.18 more. As is shown in Table 3, the total mean score of the pre-test of the control group was 0.81 more than that of the experimental group, but that of the post-test was 2.18 less. From the result of the post-test, we can see that the disparity between the experimental group is smaller than that of the control group. According to the formula of

$t=\frac{X-\mu_{0}}{S / \sqrt{n-1}}$, we got $\mathrm{t}=6.384(\mathrm{X}=67.55, \mathrm{U} 0=60.54, \mathrm{~S}=5.6$,

$\mathrm{n}=27$ ). In view of the table which provided the lower $100 \alpha \%$ point $t(n)$ for the students' distributions for different values of $\alpha$ and $n$, we find $0.05(26)=2.007$, and $\mathrm{t}>\mathrm{t} 0.05$. Therefore, Hypothesis 1 was turned down, and we concluded that flipped classroom teaching was better than the traditional teaching in developing students' comprehensive ability.

To learn about the students' autonomous learning ability, the researcher devised a questionaire, which was delivered to the students at the beginning and at the end of the experiment respectively. The questionaire consisted of 20 items in seven aspects, such as dependence on teachers' lectures, independent thinking, cooperative learning, independent learning, confidence, interest and learning strategies. The students' responses were divided into degrees: 5(strongly agree), 4(moderately agree), 3 (slightly agree), 2 (moderately disagree) and 1 (strongly disagree). The following chart demonstrates the results of the survey.

From the chart, we can see the attitudes of the experimental group towards English learning changed more greatly than those of the control group. The average degree of the experimental group at the end of the experiment was higher than that at the beginning. They were more independent of the teacher's lectures, and could make their own study plans, were more cooperative with classmates, more confident of themselves than before, and than those in the control group. Therefore, we can conclude that flipped classroom teaching has a more positive effect on students' autonomous learning, especially on promoting their independent thinking, critical thinking, collaborative learning, confidence and interest in English learning as well as learning strategies.

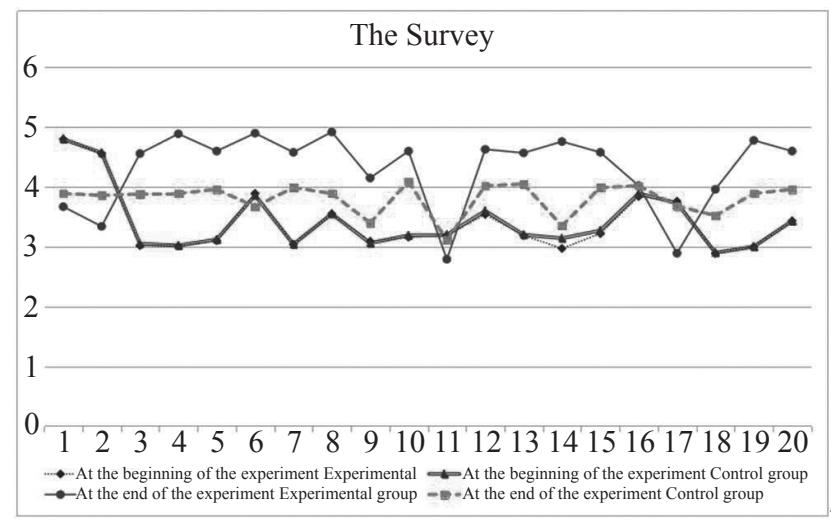

Moreover, we interviewed 20 students randomly about how flipped classroom teaching affected their autonomous learning. All of them agreed that flipped classroom teaching played a more positive role in promoting their autonomous learning abilities, cultivating their confidence and interest in learning English well, although a few students who were poorer in English found it difficult to accept the flipped classroom teaching at the beginning and preferred the traditional teaching more. Therefore, Hypothesis 2 was true.

\section{Conclusion and Consideration}

Having analyzed the collected data and results, three main trends emerged, providing insight into direct flipped classroom teaching.

\subsection{The Change of Teachers' Role}

In flipped classroom teaching based on autonomous learning theory, teachers' role is very important and their role has changed. Teachers are not the controllers or dominators in the class any more, but the organizers of the class, guides of the students. And the most important, teachers 
are the resource provider, participant and tutor. Therefore, in teaching, teachers spend more time and energy in preparing teaching materials for students to study, preview or to discuss, which is a very tough task. Moreover, teachers should encourage students, no matter whether they are right or not, to express their thinking, and to question any authority.

\subsection{The Change of Students' Role}

The role of the object of being duck-filled and passive receiver became the subject of the information processor, constructor. Students should actively participate in building the atmosphere of autonomous learning. Those students poor in English should be more active in designing tasks, carrying out tasks and evaluating, so as to promote the interest in English learning and to be more autonomous.

\subsection{The Change of the Teaching Materials}

Teaching materials should not be monotonous. The official teaching materials are the reference ones compared with those informational teaching resources. And the teaching media play the role of both teachers' teaching tools and the tools promoting students' learning, communicating. This study has raised a lot of points for consideration. The results of this study may not be generalized to other classrooms. As the experiment lasted for only one semester, the result may not accurately reflect the effect of the flipped classroom teaching. And the role of teachers is not addressed in the data; clearly, teachers play a prominent role in the flipped classroom teaching in terms of guiding and promoting students' participation. Despite these limitation, it is hoped this study serves as an opportunity for reflection on the interplay between flipped classroom teaching and traditional teaching. Students need to participate in flipped classroom teaching, but the teacher must also consider that, for some teaching materials, it prefers the traditional teaching.

\section{References}

[1] Department of Higher Education of the Ministry of Education. College English Curriculum Requirements[M]. Beijing:Qinghua University Press,2007. (in Chinese)

[2] Guidance for College English Teaching http://www.360doc. com/content/17/0203/14/413468_626210661.shtml

[3] Min Yao. On the role of the English teachers in the context of the autonomous learning[J]. Journal of Hebei Normal University (Educational Science Edition), 2008(07): 101-104. (in Chinese)

[4] Holec, H. Autonomy and Foreign Language Learning[M]. Oxford: Pergramon Press, 1981: 3.

[5] Dickinson, L. Self-instruction in Language Learning[M]. Cambridge: Cambridge University Press, 1987:5-35.

[6] Zimmerman, B. J. A social cognitive view of self-regulated academic learning[J]. Journal of Educational Psychology, 1989(3): 329-339.

[7] Little, D. Learner. Autonomy. Definitions, Issues, and Problems[M]. Dublin: Authentik, 1991: 4-12.

[8] Weiguo Pang. Self-regulated learning: Principles and Educational Applications[M].Shanghai: East China Normal University Press,2003. (in Chinese)

[9] Hua Shao, Huiqun Yu. On the Design and Construction of "Flipped Classroom"Teaching Model of College English Based on Ubiquitous Learning Resource-sharing Platform in Ubiquitous-network Age[J]. Shandong Foreign Language Teaching, 2015(06): 37-46.

[10] Han Long. An Empirical Study of Flipped English Classroom Based on Project-based Learning[J]. Journal of the Chinese Society of Education, 2015(S2):229-230. (in Chinese)

[11] Yanhui Cui, Yi Wang. Flipped Class Model and Its Application to College English Teaching[J]. China Education Technology, 2014(11):116-121. (in Chinese)

[12] Di Deng. Comments on applying flipped classroom teaching in college English teaching[J]. Foreign Language World, 2016(4):89-96. (in Chinese)

[13] Caili Bu, Baohui Zhang. Hotspots, Subjects and Future of International Flipped Classroom Researches[J]. Studies in Foreign Education, 2016(09):93-106. (in Chinese)

[14] Kekang He. Prospect of "flipped classroom" in China from the perspective of its essence[J]. E-education Research, 2014(07):5-16.

Appendix I. The Results of the Survey

\begin{tabular}{|l|c|c|c|c|}
\hline & \multicolumn{2}{|c|}{$\begin{array}{c}\text { At the beginning of } \\
\text { the experiment }\end{array}$} & \multicolumn{2}{|c|}{$\begin{array}{c}\text { At the end of the } \\
\text { experiment }\end{array}$} \\
\cline { 2 - 5 } & $\begin{array}{c}\text { Experimental } \\
\text { group }\end{array}$ & $\begin{array}{c}\text { Control } \\
\text { group }\end{array}$ & $\begin{array}{c}\text { Experimental } \\
\text { group }\end{array}$ & $\begin{array}{c}\text { Control } \\
\text { group }\end{array}$ \\
\hline $\begin{array}{l}\text { 1. I think teach- } \\
\text { er's lectures are } \\
\text { very important, } \\
\text { without which I } \\
\text { cannot study the } \\
\text { language. }\end{array}$ & 4.8 & 4.8 & 3.67 & 3.89 \\
\hline $\begin{array}{l}\text { 2. I enjoy listen- } \\
\text { ing to the teacher } \\
\text { and taking notes. }\end{array}$ & 4.56 & 4.57 & 3.34 & 3.86 \\
\hline $\begin{array}{l}\text { 3. I can solve the } \\
\text { problems in En- } \\
\text { glish learning by } \\
\text { myself. }\end{array}$ & 3.02 & 3.05 & 4.56 & 3.88 \\
\hline $\begin{array}{l}\text { 4. Wh e n the } \\
\text { teacher asks us } \\
\text { to raise questions } \\
\text { that we have met } \\
\text { with in our learn- } \\
\text { ing, I always } \\
\text { have questions to } \\
\text { ask. }\end{array}$ & 3.01 & 3.02 & 4.89 & 3.89 \\
\hline
\end{tabular}




\begin{tabular}{|c|c|c|c|c|}
\hline $\begin{array}{l}\text { 5. I like to } \\
\text { discuss with my } \\
\text { classmates about } \\
\text { the problems in } \\
\text { English learning. }\end{array}$ & 3.10 & 3.12 & 4.60 & 3.96 \\
\hline $\begin{array}{l}\text { 6. By discussing } \\
\text { with my class- } \\
\text { mates, I often } \\
\text { discover ideas } \\
\text { that have never } \\
\text { come into my } \\
\text { mind. }\end{array}$ & 3.89 & 3.86 & 4.90 & 3.67 \\
\hline $\begin{array}{l}\text { 7. I often discuss } \\
\text { with my teacher } \\
\text { in English. }\end{array}$ & 3.04 & 3.04 & 4.58 & 3.99 \\
\hline $\begin{array}{l}\text { 8. I always pre- } \\
\text { view before I go } \\
\text { to the classroom. }\end{array}$ & 3.55 & 3.55 & 4.92 & 3.89 \\
\hline $\begin{array}{l}\text { 9. If I have diffi- } \\
\text { culties in English } \\
\text { learning, I'll ask } \\
\text { my teacher for } \\
\text { help. }\end{array}$ & 3.09 & 3.06 & 4.15 & 3.40 \\
\hline $\begin{array}{l}\text { 10. If I have diffi- } \\
\text { culties in English } \\
\text { learning, I'll try } \\
\text { to solve them by } \\
\text { myself before } \\
\text { asking my teach- } \\
\text { er or classmates } \\
\text { for help. }\end{array}$ & 3.16 & 3.19 & 4.60 & 4.09 \\
\hline $\begin{array}{l}\text { 11. When others } \\
\text { give me advice, I } \\
\text { will follow it }\end{array}$ & 3.19 & 3.20 & 2.79 & 3.11 \\
\hline $\begin{array}{l}\text { 12. When others } \\
\text { give me advice } \\
\text { on learning, I will } \\
\text { consider about it } \\
\text { to see whether it } \\
\text { is suitable for me }\end{array}$ & 3.54 & 3.6 & 4.63 & 4.02 \\
\hline $\begin{array}{l}\text { 13. When I } \\
\text { disagree with my } \\
\text { teacher, I will } \\
\text { state my own } \\
\text { opinion. }\end{array}$ & 3.19 & 3.20 & 4.57 & 4.05 \\
\hline $\begin{array}{l}\text { 14. I can make } \\
\text { my own learning } \\
\text { plan. }\end{array}$ & 2.97 & 3.14 & 4.76 & 3.35 \\
\hline $\begin{array}{l}15 . \text { I can finish } \\
\text { the work by } \\
\text { myself. }\end{array}$ & 3.22 & 3.27 & 4.58 & 3.99 \\
\hline $\begin{array}{l}\text { 16. I prefer } \\
\text { teacher's positive } \\
\text { comments to } \\
\text { negative ones. }\end{array}$ & 3.84 & 3.89 & 4.02 & 4.02 \\
\hline $\begin{array}{l}17 . \text { I would like } \\
\text { our teacher to } \\
\text { assign us a lot of } \\
\text { after-class work, } \\
\text { otherwise I don't } \\
\text { know what to do } \\
\text { in my free time. }\end{array}$ & 3.76 & 3.73 & 2.89 & 3.68 \\
\hline $\begin{array}{l}\text { 18. When I find } \\
\text { something in } \\
\text { English worth } \\
\text { reading, I always } \\
\text { read it at once } \\
\text { and take notes. }\end{array}$ & 2.89 & 2.90 & 3.96 & 3.52 \\
\hline
\end{tabular}

\begin{tabular}{|l|l|l|l|l|}
\hline $\begin{array}{l}\text { 19. I'm confi- } \\
\text { dent of learning } \\
\text { English well. }\end{array}$ & 3.00 & 3.00 & 4.78 & 3.89 \\
\hline $\begin{array}{l}\text { 20. I have my } \\
\text { own learning } \\
\text { method and strat- } \\
\text { egies.. }\end{array}$ & 3.43 & 3.43 & 4.60 & 3.96 \\
\hline
\end{tabular}

Appendix II. Pre-test Control Group

\begin{tabular}{|c|c|c|c|c|c|c|}
\hline $\begin{array}{c}\text { Serial } \\
\text { No. }\end{array}$ & Writing & $\begin{array}{c}\text { Listen- } \\
\text { ing }\end{array}$ & Reading & $\begin{array}{c}\text { Transla- } \\
\text { tion }\end{array}$ & Cloze & $\begin{array}{c}\text { Total } \\
\text { Scores } \\
\end{array}$ \\
\hline 1 & 11 & 22 & 17 & 8 & 3 & 61 \\
\hline 2 & 9 & 13 & 16 & 15 & 7 & 60 \\
\hline 3 & 6 & 15.5 & 13 & 12 & 4 & 50.5 \\
\hline 4 & 10 & 16 & 15 & 11 & 3 & 55 \\
\hline 5 & 12 & 18 & 12 & 11 & 6 & 69 \\
\hline 6 & 11 & 19 & 17 & 6.5 & 3 & 56.5 \\
\hline 7 & 12 & 9 & 16 & 12.5 & 7 & 56.5 \\
\hline 8 & 11 & 16 & 18 & 8 & 4 & 57 \\
\hline 9 & 12 & 12.5 & 12 & 10 & 4 & 50.5 \\
\hline 10 & 12 & 21 & 18 & 11.5 & 4 & 66.5 \\
\hline 11 & 13 & 12 & 17 & 8.5 & 4 & 54.5 \\
\hline 12 & 12 & 20.5 & 15 & 10.5 & 6 & 64 \\
\hline 13 & 13 & 15 & 18 & 14 & 5 & 65 \\
\hline 14 & 10 & 20 & 15 & 14 & 6 & 65 \\
\hline 15 & 12 & 18 & 19 & 7.5 & 3 & 59.5 \\
\hline 16 & 12 & 13 & 16 & 6 & 2 & 49 \\
\hline 17 & 12 & 12 & 17 & 14.5 & 5 & 60.5 \\
\hline 18 & 13 & 20 & 13 & 14 & 6 & 66 \\
\hline 19 & 12 & 15.5 & 18 & 11 & 3 & 59.5 \\
\hline 20 & 13 & 19 & 20 & 14.5 & 9 & 75.5 \\
\hline 21 & 12 & 19 & 17 & 13.5 & 1 & 62.5 \\
\hline 22 & 13 & 20.5 & 17 & 14.5 & 5 & 70 \\
\hline 23 & 12 & 18.5 & 16 & 10.5 & 9 & 66 \\
\hline 24 & 9 & 14.5 & 17 & 13 & 3 & 57 \\
\hline 25 & 12 & 18.5 & 19 & 12.5 & 5 & 67 \\
\hline 26 & 11 & 6.5 & 19 & 13.5 & 1 & 51 \\
\hline 27 & 12 & 19 & 17 & 14 & 4 & 66 \\
\hline
\end{tabular}

Appendix II. Pre-test Experimental Group

\begin{tabular}{ccccccc}
\hline $\begin{array}{c}\text { Serial } \\
\text { No. }\end{array}$ & Writing & $\begin{array}{c}\text { Listen- } \\
\text { ing }\end{array}$ & Reading & $\begin{array}{c}\text { Transla- } \\
\text { tion }\end{array}$ & Cloze & $\begin{array}{c}\text { Total } \\
\text { Scores }\end{array}$ \\
\hline 1 & 11 & 18.5 & 14 & 7 & 6 & 56.5 \\
2 & 12 & 14 & 18 & 11.5 & 7 & 62.5 \\
3 & 12 & 9.5 & 18 & 11 & 6 & 56.5 \\
4 & 11 & 15.5 & 18 & 14.5 & 6 & 66.5 \\
5 & 12 & 14.5 & 20 & 12 & 6 & 64.5 \\
6 & 12 & 17.5 & 20 & 11.5 & 3 & 64 \\
7 & 13 & 19 & 20 & 12.5 & 6 & 70.5 \\
8 & 12 & 15 & 12 & 13.5 & 4 & 56.5 \\
9 & 13 & 20.5 & 13 & 14 & 5 & 65.5 \\
10 & 12 & 15 & 20 & 12 & 4 & 63 \\
11 & 12 & 17 & 15 & 14 & 4 & 62 \\
12 & 14 & 16.5 & 13 & 12.5 & 5 & 65 \\
13 & 13 & 20.5 & 16 & 12.5 & 5 & 67 \\
14 & 11 & 19 & 14 & 11 & 3 & 58 \\
15 & 12 & 13.5 & 16 & 13.5 & 4 & 59 \\
\hline
\end{tabular}


Teaching research

\begin{tabular}{ccccccc}
\hline 16 & 13 & 18.5 & 16 & 13.5 & 5 & 66 \\
17 & 12 & 22.5 & 20 & 6.5 & 4 & 65 \\
18 & 12 & 13.5 & 14 & 14 & 6 & 59.5 \\
19 & 11 & 19.5 & 20 & 10 & 4 & 64.5 \\
20 & 13 & 12.5 & 16 & 12 & 7 & 60.5 \\
21 & 10 & 18 & 17 & 10 & 4 & 59 \\
22 & 11 & 14 & 16 & 11 & 2 & 54 \\
23 & 13 & 18.5 & 9 & 14 & 4 & 58.5 \\
24 & 12 & 10 & 16 & 10.5 & 2 & 50.5 \\
25 & 12 & 18.5 & 18 & 14 & 4 & 66.5 \\
26 & 12 & 19 & 16 & 10 & 4 & 61 \\
27 & 13 & 14.5 & 20 & 11 & 1 & 59.5 \\
\hline
\end{tabular}

Appendix II. Post-test Control Group

\begin{tabular}{ccccccc}
\hline $\begin{array}{c}\text { Serial } \\
\text { No. }\end{array}$ & Writing & $\begin{array}{c}\text { Listen- } \\
\text { ing }\end{array}$ & Reading & $\begin{array}{c}\text { Transla- } \\
\text { tion }\end{array}$ & Cloze & $\begin{array}{c}\text { Total } \\
\text { Scores }\end{array}$ \\
\hline 1 & 10 & 10 & 13 & 13 & 5 & 52 \\
2 & 10 & 17 & 13 & 11.5 & 2.5 & 49 \\
3 & 13 & 19 & 20 & 13 & 2.5 & 67.5 \\
4 & 12 & 21 & 25 & 12.5 & 4 & 74.5 \\
5 & 9 & 19 & 21 & 12.5 & 5.5 & 67 \\
6 & 12 & 13 & 21 & 14 & 3.5 & 63.5 \\
7 & 13 & 15.5 & 21 & 13 & 3.5 & 66 \\
8 & 11 & 20.5 & 19 & 13.5 & 5 & 69 \\
9 & 10 & 16 & 24 & 9 & 4.5 & 63.5 \\
10 & 9 & 19 & 27 & 9.5 & 5.5 & 70 \\
11 & 9 & 16 & 23 & 14 & 5 & 67 \\
12 & 9 & 18 & 22 & 12 & 6.5 & 68.5 \\
13 & 11 & 18 & 25 & 14 & 2.5 & 70.5 \\
14 & 10 & 10 & 10 & 8.5 & 5 & 43.5 \\
15 & 12 & 16.5 & 16 & 13.5 & 5.5 & 63.5 \\
16 & 10 & 18.5 & 16 & 11.5 & 3.5 & 59.5 \\
17 & 12 & 18 & 23 & 10 & 6 & 69 \\
18 & 13 & 11 & 25 & 12.5 & 5.5 & 67 \\
19 & 11 & 19.5 & 24 & 12.5 & 6 & 73 \\
20 & 10 & 15.5 & 19 & 14.5 & 3 & 62 \\
21 & 12 & 15.5 & 22 & 13.5 & 5.5 & 68.5 \\
\hline & & & & & &
\end{tabular}

\begin{tabular}{ccccccc}
\hline 22 & 13 & 20.5 & 18 & 13.5 & 6.5 & 71.5 \\
23 & 11 & 13.5 & 23 & 11 & 5.5 & 64 \\
24 & 10 & 22.5 & 26 & 12.5 & 3 & 74 \\
25 & 12 & 13.5 & 18 & 13 & 3.5 & 60 \\
26 & 13 & 19.5 & 22 & 13 & 5.5 & 73 \\
27 & 10 & 10.5 & 28 & 14 & 5.5 & 68 \\
\hline
\end{tabular}

Appendix II. Post-test Experimental Group

\begin{tabular}{|c|c|c|c|c|c|c|}
\hline $\begin{array}{l}\text { Serial } \\
\text { No. }\end{array}$ & Writing & $\begin{array}{l}\text { Listen- } \\
\text { ing }\end{array}$ & Reading & $\begin{array}{c}\text { Transla- } \\
\text { tion }\end{array}$ & Cloze & $\begin{array}{c}\text { Total } \\
\text { Scores }\end{array}$ \\
\hline 1 & 10 & 18 & 14 & 13 & 5 & 60 \\
\hline 2 & 12 & 19.5 & 21 & 13 & 4 & 69.5 \\
\hline 3 & 10 & 19 & 18 & 12.5 & 7.5 & 67 \\
\hline 4 & 12 & 14 & 24 & 13.5 & 4.5 & 75 \\
\hline 5 & 12 & 19 & 14 & 13 & 4.5 & 52.5 \\
\hline 6 & 10 & 15.5 & 19 & 9.5 & 6 & 58 \\
\hline 7 & 13 & 14 & 14 & 5.5 & 2.5 & 49 \\
\hline 8 & 10 & 15 & 22 & 13.5 & 5 & 66.5 \\
\hline 9 & 12 & 13 & 18 & 13.5 & 6 & 62.5 \\
\hline 10 & 12 & 16.5 & 22 & 13.5 & 3.5 & 67.5 \\
\hline 11 & 10 & 17.5 & 18 & 13.5 & 5 & 64 \\
\hline 12 & 12 & 24 & 16 & 14 & 5 & 61 \\
\hline 13 & 12 & 21.5 & 20 & 13 & 4 & 70.5 \\
\hline 14 & 10 & 12 & 24 & 14 & 4.5 & 64.5 \\
\hline 15 & 12 & 12.5 & 26 & 13 & 4 & 62.5 \\
\hline 16 & 12 & 19 & 18 & 13.5 & 5 & 57.5 \\
\hline 17 & 11 & 16 & 28 & 13 & 4 & 72 \\
\hline 18 & 13 & 16 & 20 & 14 & 2.5 & 65.5 \\
\hline 19 & 10 & 11.5 & 20 & 14 & 5.5 & 61 \\
\hline 20 & 11 & 18.5 & 22 & 14 & 7.5 & 63 \\
\hline 21 & 11 & 18 & 23 & 13.5 & 4 & 69.5 \\
\hline 22 & 10 & 16 & 22 & 14 & 2 & 64 \\
\hline 23 & 12 & 14 & 30 & 12.5 & 5 & 73.5 \\
\hline 24 & 11 & 14.5 & 22 & 14 & 2 & 65.5 \\
\hline 25 & 10 & 17 & 22 & 14 & 5.5 & 68.5 \\
\hline 26 & 12 & 10.5 & 24 & 12.5 & 3 & 62 \\
\hline 27 & 11 & 12 & 23 & 13.5 & 5.5 & 65 \\
\hline
\end{tabular}

